\title{
Demonstrating the impact of your teaching: benefits of Higher Education Academy Fellowship for librarians
}

\section{Introduction}

Continuing Professional Development (CPD) is deeply embedded in all health professions and health libraries are recognised for their vital role in supporting this (Peacock, Walton, \& Booth, 2004).

Librarians in healthcare are thus expected to demonstrate professionalism by undertaking their own CPD. Many well-known routes for health librarians' CPD exist, but here we discuss one that may be less familiar, Higher Education Academy (HEA) Fellowship ${ }^{1}$. Petrinic and Urquhart (2007) found that CPD for health librarians should emphasize, amongst other things, teaching and research skills. HEA Fellowship is a way of evidencing these.

\section{What is HEA Fellowship?}

HEA Fellowship is a nationally and internationally recognised benchmark of teaching excellence at Higher Education (HE) level (AdvanceHE, 2018). It is open to anyone who teaches or supports HE students, whether or not they are employed by an HE institution. Teaching does not have to be formal timetabled sessions: for example, someone providing one-to-one support to students in an NHS library would be eligible. Creating learning materials for others to use and staff training are also valid evidence.

There are four categories, ranging from Associate (for those new to supporting or teaching HE students or with a limited teaching remit) through to Principal (for those who can demonstrate impact outside their institution). All these are assessed against the UK Professional Standards Framework (UKPSF: AdvanceHE, 2011). These are split into three areas:

- Areas of Activity. Five aspects of teaching practice covering planning, teaching, assessment, learning environments and CPD.

- Core Knowledge. Six facets of teaching practice and theory

- Professional Values. Four areas of values and ethics concerning HE teaching and learning

\section{Why HEA?}

Because HEA Fellowship is nationally recognised, it demonstrates that librarians' teaching is of equal value to that of academics and other HE teaching staff. Benefits perceived by those achieving Fellowship include having experts validate their teaching practice, enhancing their status and credibility as educators, and highlighting innovation and excellence. It also brings the opportunity to improve practice by reflective engagement with the literature and creating supportive communities of practice. Of particular value to librarians could be highlighting teaching excellence to senior management, who may be unaware of our teaching roles. (Botham, 2018; Peat, 2015; Spowart, Turner, Shenton, \& Kneale, 2016).

\footnotetext{
${ }^{1}$ The HEA is now part of AdvanceHE but the professional recognition scheme retains the HEA brand.
} 


\section{Categories of HEA Fellowship}

AdvanceHE do not regard the categories as a "ladder"- one does not have to start at Associate and work "up" (Peat, 2014). Neither are they tied entirely to role (Reid, 2018): those in relatively junior positions can attain Senior Fellowship if they demonstrate the impact of their learning and teaching activity on others. Conversely, those in senior roles may not undertake enough teaching to meet the criteria for Senior or Principal (Peat, 2014).

The core of Fellowship applications for any category is the demonstration of a reflective approach to teaching and learning activities at HE level. Obviously, a greater range of teaching activities undertaken gives wider opportunities for reflection: however, applications demonstrating reflection on a limited range of teaching are more likely to succeed than those describing a range of activities with no reflection. Thus, librarians with any kind of HE teaching role should feel able to apply for fellowship.

Many librarians in NHS libraries undertake limited amounts of HE teaching, delivering lectures and/or workshops or one-to-one support for students but not assessment or planning modules. People in these roles could consider applying for Associate. This requires evidence of two areas of activity, two areas of knowledge and "appropriate" values.

For the areas of activity, applicants must demonstrate engagement with appropriate learning and teaching activities (AdvanceHE, 2019). Applicants can choose any two of the five areas, which gives scope for those in a variety of learning support roles. For librarians, A4 (learning environments and student support) is an obvious choice. The environment and support can be in person or virtual. Guidance aimed at Learning Developers (ALDinHE, 2015) offers the following suggestions:

- Promoting inclusivity and diversity in learning

- Tailoring teaching for the needs of different groups or forms of learning (e.g. distance learning / placement students)

- Designing and maintaining effective physical and online learning environments

- Developing good practice for teaching and supporting student learning

- Ensuring availability to assist students

- Designing publicity materials

To these, librarians might add:

- Configuring your library to maximise learning opportunities

- Making your library accessible and welcoming to all.

- Ensuring collections are inclusive, reflecting the diversity of staff and patients

- Reviewing opening hours to ensure equitable access (eg for working parents, part-time students)

- Supporting students who cannot physically visit the library, eg those on placement

Reflecting on any of these aspects and the challenges faced would be valid evidence, as long as it was tied to learning and teaching at $\mathrm{HE}$ level.

Teaching and/or supporting learning (A2) is an obvious area to consider. One could reflect on:

- Which teaching methods were used and why 
- Constraints faced

- Tailoring teaching for type of group, level of students and environment.

Another area of activity that most library staff would find achievable is A5, continuing professional development. The CPD does not have to be formal courses or qualifications. Appropriate evidence would include:

- $\quad$ Reading

- Discussions with peers

- Online forums such as Learning and Teaching in HE (LTHE) Tweetchat

Your reading should allow you to cite enough pedagogical theory to provide rationales for your methods. The authors' favourite text is Getting the Buggers to Behave (Cowley, 2014) which is a practical discussion on classroom behaviour rather than complex theory.

Alongside the two chosen areas of activity, Associate Fellowship requires evidence of two aspects of the core knowledge and "appropriate" professional values. Examples of these should be highlighted throughout your account of your activities. The two areas of knowledge are subject knowledge (K1) and appropriate methods of teaching (K2). Librarians often find K1 difficult as we may not recognise that information literacy is our "core subject". Methods of teaching (K2) is much easier, and ties nicely with the areas of activity - making teaching specific to the audience, tying chosen methods to appropriate theory.

The values will chime with anyone in health professions:

- V1: Respect individual learners and diverse learning communities

- V2 : Promote participation in higher education and equality of opportunity for learners

- V3: Evidence-based approaches

- V4: Implications of wider context in which HE operates for professional practice

For Associate, promotion of the values can be in support of the teaching of others, and only "appropriate" values need to be evidenced. Evidence for V1 and V2 could include:

- Modifying teaching or one-to-one interactions to fit particular needs. Going beyond "one size fits all"

- One-to-one support, particularly for vulnerable individuals

- Supporting academic staff in making their teaching accessible to all students

- Assisting students' learning by making library resources accessible

- Enhancing accessibility of service / building to groups such as disabled students, part-time learners, returners to education, placement students.

- Raising awareness of student diversity

V3 fits in with the A5 area of activity (CPD) and also the general need for reflection and engagement with the literature. Issues around V4 will be familiar to health librarians, and could encompass legislation such as the equality duty and GDPR and standards such as professional accreditation.

Associate Fellowship is recommended for those new in post or with limited teaching responsibilities, but the "baseline" category, suitable for most people teaching in HE, is Fellowship. Fellowship requires engagement with all aspects of the UKPSF. Librarians often find A3 (assessment) particularly 
challenging, but offering informal feedback to learners is a core part of most roles. This can be used as evidence for $\mathrm{A} 3$ with sufficient reflection on how you deliver the feedback and tailor it to the situation. One can also formally incorporate feedback into teaching sessions, by setting tasks and giving feedback on the outcome. Many academics with heavy workloads will also welcome help with assessment: librarians can mark presentations, second-consider written work or mark reference lists (George, 2019).

Senior and Principal Fellowship are for those who can demonstrate leadership at local and national levels. Demonstrating leadership does not equate to having a senior or management position, it is all about showing your influence on the learning and teaching of others.

\section{Chartership or HEA Fellowship?}

When Rabbit asked "Honey or condensed milk with your bread?"

[Pooh] was so excited that he said, "Both," and then, so as not to seem greedy, he added, "but don't bother about the bread, please." (Milne, 1926, p. 14)

Readers may be puzzling about why we are advocating HEA Fellowship rather than chartership of our professional body, CILIP. We would urge librarians to consider doing both! They are conceptually similar exercises, involving reflection on aspects of professional practice and producing evaluative statements. The intended audiences are different: whilst chartership is the standard recognised by librarians, most academics and other workers in HE are unfamiliar with it, but are well aware of HEA.

The UKPSF, the criteria for HEA fellowship (AdvanceHE, 2011) look superficially very different from the Professional Knowledge and Skills Base (PKSB) for Chartership (CILIP, 2016). However, there is considerable overlap. We have produced example mappings of the UKPSF against the PKSB. Librarians wishing to investigate HEA fellowship could do a preliminary exercise, determining which of their Chartership examples could be re-purposed for HEA fellowship.

\section{[Table 1: CILIP PKSB mapped against HEA UKPSF]}

\begin{tabular}{|c|c|c|}
\hline \multicolumn{2}{|c|}{ CILIP PKSB } & HEA UKPSF \\
\hline 1 & Organising Knowledge and Information & \\
\hline 2 & Knowledge and Information Management & \\
\hline 2.5 & Knowledge transfer/organisational learning & $\mathrm{A} 2$ \\
\hline 2.7 & Knowledge sharing and collaboration: & A5 \\
\hline 3 & Using and Exploiting Knowledge and Information & $\begin{array}{l}\text { Could be used } \\
\text { for K1. }\end{array}$ \\
\hline 3.2 & Understanding information seeking behaviour & K3 \\
\hline 4 & $\begin{array}{l}\text { Research Skills, especially: } \\
4.1 \text { Understanding Research }\end{array}$ & $\begin{array}{l}\text { Could be used } \\
\text { for K1 }\end{array}$ \\
\hline 4.5 & Understanding research contexts & V4 \\
\hline 4.7 & Research Ethics & V4 \\
\hline 5 & Information Governance and Compliance & V4 \\
\hline 6 & Records Management and Archiving & \\
\hline 7 & Collection Management and Development & $A 4, V 1, V 2$ \\
\hline 8 & Literacies and Learning & $A 1, A 2, A 3$ \\
\hline
\end{tabular}




\begin{tabular}{|l|l|l|}
\hline & & $\begin{array}{l}\text { (potentially), A4, } \\
\text { K1, K2, K3, K4, } \\
\text { K5 }\end{array}$ \\
\hline 9 & Leadership and Advocacy & Senior / Principal \\
\hline 10 & Strategy planning and management & Senior / Principal \\
\hline 11 & Customer Focus, Service Design and Marketing & $\mathrm{A} 4$ \\
\hline 12 & IT \& Communications & $\mathrm{K} 4$ \\
\hline & Wider Library, Information and Knowledge Sector context & V4 \\
\hline & Wider Organisation/Environmental context & $\mathrm{K} 6, \mathrm{~V} 5$ \\
\hline
\end{tabular}

Table 2: HEA UKPSF mapped against CILIP PKSB

\begin{tabular}{|c|c|c|}
\hline \multicolumn{2}{|r|}{ HEA UKPSF } & CILIP PKSB \\
\hline A1 & Design and plan learning activities and/or programmes of study & 8 \\
\hline A2 & Teach and/or support learning & $\begin{array}{l}8 \\
2.5\end{array}$ \\
\hline A3 & Assess and give feedback to learners & 8, potentially \\
\hline A4 & $\begin{array}{l}\text { Develop effective learning environments and approaches to } \\
\text { student support and guidance }\end{array}$ & $\begin{array}{l}7 \\
8 \\
11\end{array}$ \\
\hline A5 & $\begin{array}{l}\text { Engage in CPD in subjects / disciplines and their pedagogy, } \\
\text { incorporating research, scholarship }\end{array}$ & Any, especially 2.7 \\
\hline K1 & The subject material & $\begin{array}{l}3 \\
4 \\
8\end{array}$ \\
\hline K2 & $\begin{array}{l}\text { Appropriate methods for teaching, learning and assessing in the } \\
\text { subject area and at the level of the academic programme }\end{array}$ & 8 \\
\hline K3 & $\begin{array}{l}\text { How students learn, both generally and within their } \\
\text { subject/disciplinary area(s) }\end{array}$ & $\begin{array}{l}3.2 \\
8\end{array}$ \\
\hline K4 & The use and value of appropriate learning technologies & $\begin{array}{l}8 \\
12\end{array}$ \\
\hline K5 & Methods for evaluating the effectiveness of teaching & 8 \\
\hline K6 & $\begin{array}{l}\text { The implications of quality assurance and quality enhancement } \\
\text { for academic and professional practice with particular focus on } \\
\text { teaching }\end{array}$ & $\begin{array}{l}\text { Wider } \\
\text { Organisation/Enviro } \\
\text { nmental context }\end{array}$ \\
\hline V1 & Respect individual learners and diverse learning communities & 7 \\
\hline V2 & $\begin{array}{l}\text { Promote participation in higher education and equality of } \\
\text { opportunity for learners }\end{array}$ & 7 \\
\hline V3 & $\begin{array}{l}\text { Use evidence-informed approaches and the outcomes from } \\
\text { research, scholarship and continuing professional development }\end{array}$ & Any \\
\hline V4 & $\begin{array}{l}\text { Acknowledge the wider context in which higher education } \\
\text { operates recognising the implications for professional practice }\end{array}$ & $\begin{array}{l}4.5 \\
4.7 \\
5 \\
\text { Wider } \\
\text { Organisation/Enviro } \\
\text { nmental context }\end{array}$ \\
\hline $\begin{array}{l}\text { Senior / } \\
\text { Principal }\end{array}$ & Case studies demonstrating impact & $\begin{array}{l}9 \\
10\end{array}$ \\
\hline
\end{tabular}




\section{Conclusion}

The authors would strongly urge colleagues working in health libraries to consider applying for HEA fellowship. In these times of shrinking budgets it is vital for our profession to demonstrate our professionalism and pedagogic credentials. HEA gives you the opportunity to go back to the evidence base. You will explore, or revisit, learning theory, seek out best practice and scan the horizon for future developments, giving you more confidence in your own teaching and learning support interventions.

Librarians achieving Fellowship can raise the profile of the library within a larger service, validate librarians' role as pedagogic and intrinsic to the learning process and highlight where our teaching contributes to institutional aims. Health librarians working with other professions committed to CPD and demonstrating their evidence base can use HEA accreditation to demonstrate equality of practice.

"Becoming a Fellow has given me extra confidence in my ability - it's an achievement to have it. It's particularly useful within the NHS when working with teaching professionals across the trust. It helps demonstrate that we're working at the same level and demonstrates my professional ability."Georgina Wildman, Senior Library Assistant, NHS Support (Narcross, 2016)

Librarian jobs in HE libraries increasingly have HE fellowship as a desirable quality, while if applying to healthcare organisations, HEA accreditation makes a great discussion point: you can prove that you know how to assess the needs of your users and design activities, information and services to meet those needs. It can thus form a bridge between different types of institution.

Any teaching and learning activities at $\mathrm{HE}$ level are acceptable evidence, and a reflective approach is more important than a range of teaching. Anyone interested might like to join the mailing list for librarians interested in HEA: LIS-HEASUPPORT@jiscmail.ac.uk.

\section{Reference list}

AdvanceHE. (2011). UK Professional Standards Framework (UKPSF). Retrieved from https://www.heacademy.ac.uk/download/uk-professional-standards-framework-ukpsf

AdvanceHE. (2018). HEA Fellowship. Retrieved from https://www.heacademy.ac.uk/individuals/fellowship

AdvanceHE. (2019). Associate Fellow Higher Education Academy. Retrieved from https://www.heacademy.ac.uk/individuals/fellowship/associate-fellow\#.

ALDinHE. (2015). CPD Reverse-Mapped Planning resource. Retrieved from https://aldinheprofdev.files.wordpress.com/2010/10/ld-maps-reversed-mapping-aug2015.pdf

Botham, K. A. (2018). The perceived impact on academics' teaching practice of engaging with a higher education institution's CPD scheme. Innovations in Education and Teaching International, 55(2), 164-175. doi:10.1080/14703297.2017.1371056

CILIP. (2016). The Professional Knowledge and Skills Base for Health. Retrieved from https://cdn.ymaws.com/www.cilip.org.uk/resource/resmgr/cilip new website/careers hub Lpksb for health self assessm.pdf

Cowley, S. (2014). Getting the buggers to behave (Fifth ed.). London: Bloomsbury. 
George, S. (2019). Don't shush! Why librarians should embrace HEA Fellowship. Retrieved from https://softlaunch.advancehe.creode.co.uk/news-and-views/librarians-dont-shush

Milne, A. A. (1926). Winnie-the-Pooh. London: Methuen 1988 edition.

Narcross, J. (2016). Supporting Imperial's great teachers. Retrieved from https://www.imperial.ac.uk/news/174668/supporting-imperials-great-teachers/

Peacock, D., Walton, G., \& Booth, A. (2004). The role of library and information services in supporting learning. In G. Walton \& A. Booth (Eds.), Exploiting knowledge in health services. London: Facet Publishing.

Peat, J. (2014). UKPSF: A vehicle for development or hierarchical ladder. Educational Developments, 15(2), 16-19.

Peat, J. (2015). Getting down to the nitty-gritty: the trials and tribulations of an institutional professional recognition scheme. Perspectives: Policy and Practice in Higher Education, 19(3), 92-95. doi:10.1080/13603108.2015.1029999

Petrinic, T., \& Urquhart, C. (2007). The education and training needs of health librarians -the generalist versus specialist dilemma. Health Information \& Libraries Journal, 24(3), 167-176. doi:10.1111/j.1471-1842.2007.00717.x

Reid, M. (2018). Seniority has nothing to do with it! | Higher Education Academy. Retrieved from https://www.heacademy.ac.uk/blog/seniority-has-nothing-do-it

Spowart, L., Turner, R., Shenton, D., \& Kneale, P. (2016). 'But I've been teaching for 20 years...': encouraging teaching accreditation for experienced staff working in higher education. International Journal for Academic Development, 21(3), 206-218.

doi:10.1080/1360144X.2015.1081595 